Khanal, N.B., M.K, Shrestha, S. Rai and R.C. Bhujel 2014. Comparative evaluation of Carp testis as an alternative to 17 $\alpha$-Methyltestosterone on Tilapia sex reversal. Our Nature 12 (1): 1-7. DOI: http://dx.doi.org/10.3126/on.v12i1.12251

\title{
Comparative Evaluation of Carp Testis as an Alternative to $17 \alpha$-Methyltestosterone on Tilapia Sex Reversal
}

\author{
Nabin Babu Khanal ${ }^{1}$, M.K. Shrestha ${ }^{1}$, Sunila Rai $^{1}$ and R.C. Bhujel ${ }^{2}$ \\ ${ }^{1}$ Agriculture and Forestry University, Nepal \\ ${ }^{2}$ Asian Institute of Technology, Thailand \\ Email: nabinbabukhanal@gmail.com
}

Received: 19.04.2014; Accepted: 27.11.2014

\begin{abstract}
$17 \alpha$-Methyltestosterone (MT) is a commonly used synthetic androgen for the all male tilapia fry production. The probable residual effect of MT on human health and environment has been a concern. Two trials for two seasons were conducted to evaluate the effectiveness of carp testis (CT), as a source of natural androgen, on sex reversal of Nile tilapia (Oreochromis niloticus) and compare it with MT at Department of Aquaculture, Agriculture and Forestry University, Nepal, using completely randomised block deign (RCBD). Altogether 8 treatments with 4 for methyltestosterone (40 mg MT $\mathrm{kg}^{-1}$ of diet) and 4 for $75 \%$ rohu (Labeo rohita) testis. Both source of androgen were fed for $15,18,21$ or 24 days. Treatments were replicated thrice. The result of methyltestosterone feeding for 24 days showed significantly $(\mathrm{p}<0.05)$ higher percentage of male $(98.5 \pm 1.5)$ than 15 days $(87.1 \pm 3.5)$ but was statistically similar with 18 $(91.8 \pm 2.6)$ and $21(94.3 \pm 3.0)$ days feeding. Similarly percentage of male obtained with18 $(84.8 \pm 2.1)$ and $21(85.8 \pm 2.9)$ days of CT feeding were statistically similar(p>0.05) with 24 days and also with 15 days CT treatment but the result of 24 days CT feeding was significantly higher $(91.4 \pm 1.2)$ than 15 days $(82.5 \pm 2.7)$ of carp testis feeding.
\end{abstract}

Key words: $17 \alpha$-methyltesterone (MT), carp testis (CT), sex reversal

\section{Introduction}

Nile tilapia (Oreochromis niloticus) is one of the important species cultured in Asia and represents about $70 \%$ of global production in 2007 with steady growth rate of $15 \%$ (Josupeit, 2007). The intensification of its production system has increased demand of mono-sex male fry. Though, Nile tilapia was introduced in Nepal since 1985 (Pulin, 1986; Pantha, 1993; Singh, 1995), it remained inside government farm for long time and were not made available to farmers (Shrestha and Bhujel, 1999). One of the major constraints of tilapia farming with mixed-sex population is inherently high reproductive capacity resulting from early maturity, highly developed parental care, and multiple spawning cycles. Generally fish species used in aquaculture will not reproduce in the culture environment before reaching market size but most species of tilapia, under favourable growth conditions, will reach maturity within 6-8 month of hatching at a size less than $100 \mathrm{~g}$. Under favourable conditions they will continue to reproduce, the offspring competing with the initial stock for food, resulting in stunted growth and unmarketable fish (Phelps and Popma, 2000). Various techniques, including stock manipulation (Swingle, 1960), polyculture 
Nabin Babu Khanal, M.K. Shrestha, Sunila Rai and R.C. Bhujel / Our Nature (2014), 12(1): 1-7.

of tilapia with predatory fish (Lovshin, 1975) and mono-sex culture (Shell, 1968) have been develop to control overpopulation. The use of a predator does not prevent reproduction but only prevent recruitment that reduces production due to the slower growing females. All male tilapia culture is preferred due to the faster growth rate of male tilapia (Guerrero 1975; Shelton et al. 1978, Guerrero and Guerrero 1988).

Sex reversal with $17 \alpha$-methyl testosterone is one of the most commonly applied techniques to produce mono-sex male populations in tilapia. This technique has shown very good results both at experimental and commercial stages. However, little is known about the actual impact of the residuals on the human health and environment (Desprez et al., 2003, and Mengumphan et al., 2006). Thus, the controversial health and environmental issue needs new alternative methods to produce all-male tilapia populations. Such alternatives may include phytochemicals or other natural sources that exhibit endocrine disruptive activity and they interfere with various enzymatic reactions either in steroid metabolism (aromatization) or in the mechanism of steroid action (Dabrowski et al., 2007; Meyer et al., 2008 and Phelps et al., 1996). Positive results towards the sex reversal of tilapia to male were obtained with bull testis (Phelps et al., 1996), hog testis (Mayer et al., 2008), and ram testis (Haylor and Pascual, 1991). However, there is no research using fish testis for sex reversal. Therefore, this study tries to explore the possibility of carp testis as a hormone source in sex reversal of Nile tilapia.

\section{Materials and methods}

An experiment was carried out at Department of Aquaculture, Agriculture and Forestry University, Nepal.

\section{Treatment design}

Two sources of androgen i.e. synthetic (40 mg $17 \alpha$-Methyltestosterone fed for 15,18 , 21 or 24 days) and natural (75\% dried and minced Labio rohita testis fed for 15, 18, 21 or 24 days), were fed as experimental diet under randomized complete block design (RCBD) with 3 replication for each source. The trials were performed for two seasons.

First feeding larvae, 5 day old larvae, were randomly distributed to $0.6 \times 0.25 \times 0.25$ $\mathrm{m}^{3}$ nylon hapas suspended in indoor treatment unit. The hapas were supplied continuously with tap water. With the completion of treatment, fries were reared in outdoor $0.7 \times 0.7 \times 1 \mathrm{~m}^{3}$ grow out hapas suspended in cemented tank of $5 \times 5 \times 1.5$ $\mathrm{m}^{3}$ until they attained minimum size of $2 \mathrm{~g}$ for gonadal exanimation.

\section{Statistical analysis}

Data were analysed through one way ANOVA for treatments of each androgen source. DMRT was used to compare the means of significant result. Relative efficiency of carp testis and $17 \alpha$ Methyltestosterone were compared through single degree of freedom orthogonal polynomial contrast.

\section{Feed Preparation and feeding}

Methyltestosterone treated diet was prepared as described by Phelps et al. (1996). The $40 \mathrm{mg} 17 \alpha$-Methyltestosterone was dissolved in $500 \mathrm{ml}$ of $95 \%$ ethanol which was later mixed with $1 \mathrm{~kg}$ of the powdered fish meal. Ethanol was evaporated from the alcohol-diet mixture by keeping diet under fan for 24 hours in 
Nabin Babu Khanal, M.K. Shrestha, Sunila Rai and R.C. Bhujel / Our Nature (2014), 12(1): 1-7.

shade. Shade dried feed was kept in refrigerator till use.

Rohu (Labio rohita) testes were collected from local fish market of Narayangarh, Chitwan, Nepal. Collected testes were cut into small pieces and dried under fan. Dried testes were minced into fine powder and mixed with fish meal (3:1 rohu testis to fish meal ratio) and kept in refrigerator for feeding.

MT and CT treated feed were fed $20 \%$ of body weight for the first week (Table 1). The feeding rate was reduced by $2.5 \%$ per week from second week onward until it reaches $5 \%$ of body weight. This was adjusted weekly based on results of weekly population samples.

During the outdoor rearing period all the hapas were fed with the diet containing $35 \% \mathrm{cp}$ at the rate of $5 \%$ of body weight twice a day.

Table 1. Composition of feed for treatment and nursing during the experiment conducted at Department of Aquaculture, Agriculture and Forestry University, Nepal.

\begin{tabular}{ll}
\hline Treatment & Nursery \\
\hline & \\
MT Feed & Fish meal 50\% (45\% CP) \\
Fish meal 100\% & $\begin{array}{l}\text { Soyabean 20\% (42\% CP) } \\
\text { Rice police 29\% }(12 \% \mathrm{CP})\end{array}$ \\
CT Feed & Min/vit mixture $-1 \%$ \\
Fish meal 25\% & \\
Carp testis 75\% & \\
\hline
\end{tabular}

\section{Sex determination}

Gonadal examination and sex expression was performed according to Guerrero and Shelton (1974). Fish were dissected by making a cut near the anus to below the base of the pectoral fin. The entire gonad, located on the dorsal portion of the peritoneal lining was removed carefully beginning ventrally and going forward. All length of gonad was kept on slide and given a drop of dye. A cover slip was placed over the gonad and gently pressed it for squashing the gonads. When larger fish were examined an obvious ovary with readily apparent eggs were seen in the body cavity, but on occasions, the gonad may also contain testicular tissue (ovotestis or intersex). Thick gonads were sliced longitudinally to examine properly. The entire length of gonad should be examined to see if it contains only one type of gonadal tissue (Fig:1-3).

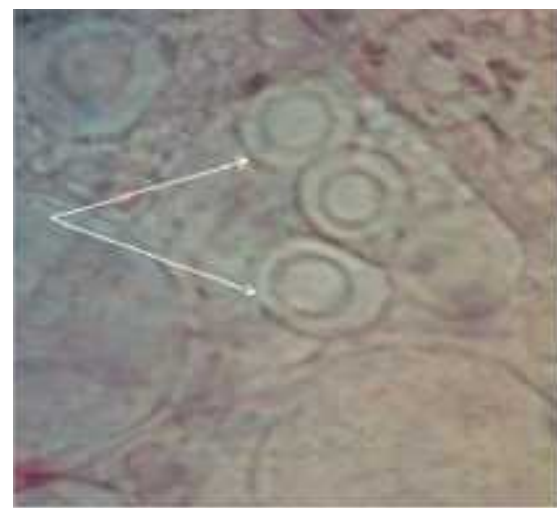

Figure 1. Oogonia observed during gonadal squash of ovary (indicated by white arrow)

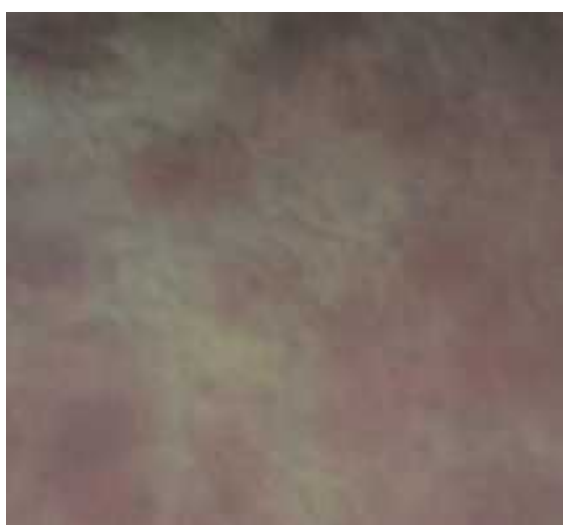

Figure 2. Ovotestis observed during gonadal squash of Nile tilapia fry (indicated by patches of undifferentiated cloudy cells). 


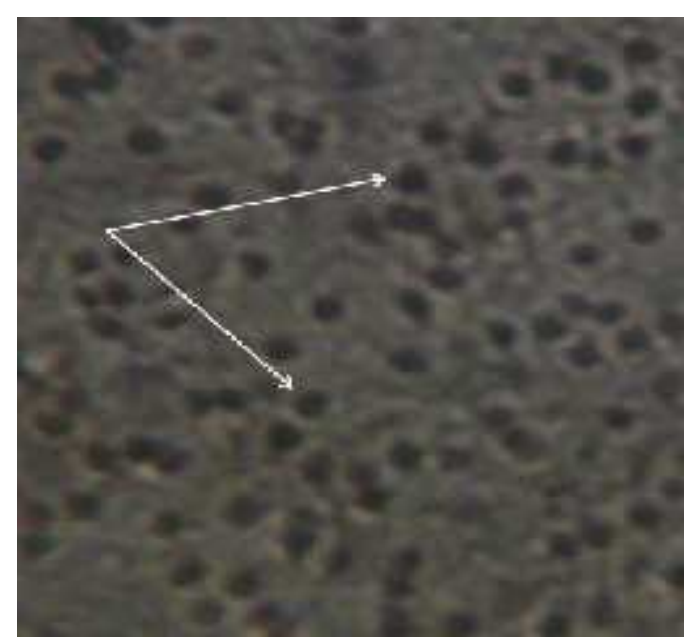

Figure 3. Spermatogonia observed during gonadal squash of testis (indicated by white arrow).

\section{Results}

\section{Sex expression of fry/fingerling}

The phenotypic male percentage was found increase with increasing methyltestosterone feeding days from 15 to 24 (Table 2). MT feeding for 24 days gave statistically higher $(\mathrm{p}<0.05)$ and maximum male population $(98.5 \pm 1.5 \%)$ than 15 days feeding. Statistically similar male population were obtained with 18 and 21 days of MT feeding which were also statistically at par with 15 and 24 days of MT feeding.

Regarding the expression of phenotypic maleness, carp testis (CT) also express same trend as by Methyltestosterone. Lower percentage of male (82.5 $\pm 2.7 \%$ ) was obtained with CT fed for 15 days which was significantly lower $(\mathrm{p}<0.05)$ than the male percent $(91.4 \pm 1.2 \%)$ obtained with CT fed for 24 days. Carp testis fed for 18 and 21 days produced statistically similar phenotypic male which were also at par with 15 and 24 days of CT feeding.

Considering the sources of androgen, $17 \alpha$-Methyltestosterone produced statistic- ally $(\mathrm{p}<0.05)$ higher average male population $(92.9 \pm 1.5 \%)$ than carp testis $(85.9 \pm 1.3 \%)$.

Intersex fish were observed in very low frequency under both methyltestesterone and carp testis treatment. For both androgen sources higher percentage of intersex fish were observed under 21 days feeding while decreasing trend were observed for either increasing or decreasing the hormone feeding days. Average intersex fish were higher with methyltesterone but were statistically at par (Table 2).

\section{Water quality}

The average indoor temperature of season I $\left(25.4 \pm 0.23^{\circ} \mathrm{C}\right)$ was statistically different $(\mathrm{p}<$ $0.002)$ than season II $\left(24.06 \pm 0.03^{\circ} \mathrm{C}\right)$. Similarly, the average outdoor grow out unit's temperature of season I $\left(21.12 \pm 0.83^{0} \mathrm{C}\right)$ was also significantly different $\quad(\mathrm{p}<0.000)$ with season II $\left(28.84 \pm 0.7^{0} \mathrm{C}\right)$. During indoor hormone feeding both seasons had almost same minimum $\left(24.83^{\circ} \mathrm{C}\right.$ and $24^{\circ} \mathrm{C}$ for season I and II respectively) and maximum $\left(26^{\circ} \mathrm{C}\right.$ and $24.2^{\circ} \mathrm{C}$ for season I and II respectively) temperature. Outdoor unit of first season had decreasing water temperature trend up to $15.3^{\circ} \mathrm{C}$ which was unfavourable for tilapia growth.

The $\mathrm{pH}$, Dissolved oxygen (DO), total alkalinity, hardness, total ammonium nitrogen (TAN) and soluble reactive phosphorus (SRP) were found at desirable during indoor treatment and outdoor grow out unit for both season of experiment.

\section{Discussion}

Methyltestosterone (MT) feeding days when increased from 15 to 24 days, male tilapia population was also increased from $87.1 \pm 3.4 \%$ to $98.5 \pm 1.5 \%$. Increasing male 
Nabin Babu Khanal, M.K. Shrestha, Sunila Rai and R.C. Bhujel / Our Nature (2014), 12(1): 1-7.

Table 2. Phenotypic male and intersex $(\%$, mean \pm SE) Nile tilapia observed under different days of $17 \alpha$ methyltestosterone (MT) and carp testis (CT) feeding at Department of Aquaculture, Agriculture and Forestry University, Nepal

\begin{tabular}{lcccc}
\hline \multirow{2}{*}{ Treatment } & \multicolumn{2}{c}{ Maleness \% } & \multicolumn{2}{c}{ Intersex \% } \\
\cline { 2 - 5 } & MT & CT & MT & CT \\
\hline 15 days feeding & $87.1 \pm 3.5^{\mathrm{a}}(9.3)$ & $82.5 \pm 2.7^{\mathrm{a}}(9.1)$ & $0.0 \pm 0.0(0.7)$ & $0.0 \pm 0.0(0.8)$ \\
18 days feeding & $91.8 \pm 2.6^{\mathrm{ab}}(9.6)$ & $84.8 \pm 2.1^{\mathrm{ab}}(9.2)$ & $1.7 \pm 1.1(4.9)$ & $0.0 \pm 0.0(0.8)$ \\
21 days feeding & $94.3 \pm 3.0^{\mathrm{ab}}(9.7)$ & $85.8 \pm 2.9^{\mathrm{ab}}(9.3)$ & $2.9 \pm 2.1(6.1)$ & $1.9 \pm 1.2(5.0)$ \\
24 days feeding & $98.5 \pm 1.5^{\mathrm{b}}(10.0)$ & $91.4 \pm 1.2^{\mathrm{b}}(9.6)$ & $1.5 \pm 1.5(3.6)$ & $1.0 \pm 1.0(2.9)$ \\
MT $V$ S CT & $92.9 \pm 1.5^{\mathrm{a}}(9.6)$ & $85.9 \pm 1.3^{\mathrm{b}}(9.3)$ & $1.5 \pm 0.6(3.8)$ & $0.7 \pm 0.5(2.4)$ \\
\hline
\end{tabular}

population with increasing hormone feeding days was also supported by Phelps et al. (1996), Macinthos et al. (1993), Nakamura and Iwashi (1982), Guerro and Guerro (1988) and Mbarereehe (1992). Phelps et al. (1996) got $92 \%$ male population when 60 mg MT was fed for 21 days while same diet gave only $65 \%$ male when fed for 14 days. Macinthos et al. (1993) got 58 to $79 \%$ male tilapia when fed $30 \mathrm{mg}$ MT from 30 to 60 days. Nakamura and Iwashi (1982) and Guerro and Guerro (1988) also reported more than $95 \%$ male population when tilapia were treated with oral administration of 30 to $60 \mathrm{mg}$ MT $\mathrm{Kg}^{-1}$ of diet for 3 to 4 week. Mbarereehe (1992) found 95\% male population with 40 days feeding at $18-22^{\circ} \mathrm{C}$ while only $69 \%$ males with 20 days feeding.

The increased male population with increased MT feeding days was might be due to increase total amount of androgen consumption. The higher percentage of male population with higher amount of MT consumed was reported by Mainardes-Pinto et al. (2000), Okoko (1996), Macinthos et al. (1983), Marjani et al. (2009) and Mengumphan et al. (2006). MainardesPinto et al. (2000) reported significantly higher male population with $30 \mathrm{mg}$ MT than control diet while increasing the MT concentration to $60 \mathrm{mg}$ further increase the male population to $98 \%$. Okoko (1996) also observed the increase in male population from 58 to $99.3 \%$ when he fed diet containing 0 to $60 \mathrm{mg}$ MT. But he observed decreaed male population with 120 to 1200 $\mathrm{mg}$ MT kg${ }^{-1}$ of diet then $60 \mathrm{mg}$ MT. Marjani et al. (2009) reported 51.96\%, 74.29\% and $98.09 \%$ male population with control, 50 $\mathrm{mg}$ and $75 \mathrm{mg} \mathrm{MT} \mathrm{Kg}^{-1}$ of diet when fed for 21 days.

In this study males were at least $82.5 \pm 2.7 \%$ when Nile tilapia fed with $75 \%$ carp testis for 15 days to at most of $91.4 \pm 1.2 \%$ with 24 days feeding which were higher than the natural population of 50:50 male and female ratio. Different results with different source testis feeding also support the sex reversal potentiality of testis. Phelps et al. (1996) reported the sex reversal potentiality of freeze dried bull testis. He observes significantly higher male population $(64.8 \%)$ then control group when they fed $50 \%$ bull testis. But he observed non significant male population (52.4\%) with 25\% bull testis. Phelps et al. (1996) was also supported by Meyer et al. (2008) who produced $87 \%$ male population with freeze dried fresh bull testis. The sex reversal potentiality was reported from ram testis also. Hylor and Pascual (1991) reported significantly higher male population $(85.14 \%)$ with $57 \%$ ram testis then control diet. Similarly, $83 \%$ male were 
reported by Meyer et al. (2008) with hog testis. Natural androgens that cause sex reversal of tilapia was also reported from phyto-extract by Stadtlander et al. (2008), Dabrowaski et al. (2007), Mengumphan et al. (2006).

The average performance of $17 \alpha$ methyltestosterone group had significantly higher male population $(92.9 \pm 1.5 \%)$ then carp testis group $(85.9 \pm 1.3 \%)$. This result was in favour with Phelps et al. (1996). They got more than $97 \%$ male with 15, 30, 45 or $60 \mathrm{mg}$ MT $\mathrm{Kg}^{-1}$ of diet which was significantly higher than male produced ( $64.8 \%$ ) with $50 \%$ freeze dried bull testis. Mengumphan et al. (2006) fed chitralada strain of Nile tilapia with control diet, synthetic androgen (40 and $60 \mathrm{mg}$ MT) and natural androgen $(100 \mathrm{~g}, 200 \mathrm{~g}$ and $300 \mathrm{~g}$ dried root powder of Buta superba $\mathrm{kg}^{-1}$ of diet). He observed more male with both source of androgen when concentration was increased. The average male was $84.25 \%$ which was higher than the average performance of natural androgen (61.1\%).

\section{Conclusion}

The Labeo rohita testis was found effective for the conversion of female tilapia into phenotypic male tilapia. The refinement of testis could produce more male population which could permanently replace the use synthetic androgen (17 $\alpha$ - methyltesterone) for tilapia sex reversal and side by side solve the issue related to human health and environment.

\section{Acknowledgements}

I would like to acknowledge my gratitude to department of aquaculture, AFU, Nepal for providing me the research venue. My special gratitude goes to Nepal Agriculture Research and Development Fund (NARDF) for providing research grant for completion of this research. I am also highly gratitude to the co-author for their continuous feedback and support during the research.

\section{References}

Dabrowski K., G. Rodríguez and L. Frantz. 2007. Use of Phytochemicals as a new method to sex-reverse nile tilapia and tropical garfish. Part I: Use of aqueous plant extracts in tilapia (12FNF3a). Twenty-fourth aquaculture CRSP annual technical report, Oregon State University, Corvallis, Oregon. 24:117-121.

Desprez, D., E. Geraz, M.C. Hoareau, C. Melard, P. Bosc and J.F. Baroiller. 2003. Production of a high percentage of male offspring with a natural androgen, 11B-hydroxyandrostenedione (11BOHA4), in Florida red tilapia. Aquaculture 216:55-65.

http://dx.doi.org/10.1016/S0044-8486 (02)00276-4

Guerrero III, R.D. 1975. Use of androgens for the production of all male Tilapia aurea (Steindachner). Transactions of the American Fisheries Society 104:342-348. http://dx.doi.org/10.1577/15488659(1975)104\%3C342:UOAFTP\%3E2.0.CO;2

Guerrero III, R.D. and W.I. Shelton. 1974. An acetocarmine squash method for sexing juvenile fishes. The progressive fish-culturist $\mathrm{pp}$. 36:56.

Guerrero, R.D., III and L.A. Guerrero. 1988. Feasibility of commercial production of sexreversed Nile tilapia fingerlings in the Philippines. In The second international symposium on tilpia in Aquaculture (Eds. R.S.V. Pullin, T. Bhukaswan, K. Tonguthi, and J.L. Maclean). ICLARM conference proceeding 15, department of fisheries, Bangkok, Thailand, and international center for living aquatic resources managemnt, Manila, Philippines. pp. 183-186.

Haylor, G.S. and A.B. Pascual. 1991. Effect of using ram testis in a fry diet for Oreochromis niloticus (L.) on growth, survival and resultant phenotypic sex ratio. Short communication. Institute of Aquaculture, University of Starlings, Stirling, Scotland. pp. 4.

Josupeit H. 2007. World tilapia trade. FAO, globefish, infofish tilapia conference, Kuala Lumpur, August. Available on: fishsite.com [Retrived: 6 september, 2009] 
Nabin Babu Khanal, M.K. Shrestha, Sunila Rai and R.C. Bhujel / Our Nature (2014), 12(1): 1-7.

Lovshin, L.L. 1975. Tilapia hybridization. In The biology and culture of tilapias (Eds. R.S.V. Pullin and R.H. Lowe McConnell). ICLARM conference proceedings 7. International center for living resources management, Manila, Philippines. pp. 279-308

Macinthosh, D.J., T.J. Varghese and G.P. Satyanarayanarao. 1983. Hormonal sex reversal of wild spawned tilapia in India. Journal of fish biology 26(2):87-94. http://dx.doi.org/10.1111/ j.1095-8649.1985. tb04245. x

Mainardes-Pinto, C.S.R., N. Fenerich-Verani, B.E.S. de Campos and A.L. da Silva. 2000. Masculinization of nile tilapia, Oreochromis niloticus, using different diets and different doses of $17 \alpha$-methyltestosterone. Rev. bras. zootec 29(3):654-659. http://dx.doi.org/10.1590/S151635982000000300003

Marjani, M., S. Jamili, P.G. Mostafavi, M. Ramin and A. Mashinchan. 2009. Influence of 17-alpha methyl testosterone on masculinisation and growth in tilapia (Oreochromis mossambicus). Journal of fisheries and aquatic science 4(1):7174. http://dx.doi.org/10.3923/jfas.2009.71.74

Mbrarererehe, F. 1992. Contribution a letude de linfluencede la temperature et la duree de traitment sur la production des alevins monosexes $\mathrm{du}$ Tilapia nilotica. Memorie presente en vue de 1 obtention du diploma d ingenieur technician. Institut Superieur d Agriculture et d'Elevage de busogo, Ruhengeri, Rwanda.

Mengumphan, K., Y. Samitasiri and R. Carandangjr. 2006. The potential of red kwao kreua (Butea superba) in inducing sex reversal on three strains (Red, Ghana, Chitralada) of nile tilapia (Oreochromis niloticus L.) and the effect of 17- $\alpha$ methyltestosterone (MT). Asian fisheries science 19:271-279.

Meyer, D., M. Guevara, W. Chan and C. Castillo. 2008. Use of fresh bull and hog testis in sex reversal of nile tilapia fry. In world aquaculture 2008, Busan Korea, 19-23 May, 2008.

Nakamura, M. and M. Iwabashi. 1982. Studies on the practical masculinisation in tilapia nilotica by oral administration of androgen, bull. Japan society of science and fish 48:736-769. http://dx.doi.org/10.2331/suisan.48.763

Okoko, M. 1996. Effects of methyltestosterone concentration on sex ratio, growth and development of Nile tilapia, Oreochromis niloticus. Master's thesis, Auburn University, AU, USA.
Pantha, M.B. 1993. Aqua feeds and feeding strategy in Nepal. In Farm made aqua-feeds (Eds. M. W.

New. A.G.T. Tacon and I. Csavas). Proceeding of the FAO/AADCP regional expert consultation on farm-made Aqua feeds. 14-18 December 1992. Bangkok, Thailand. FAO-RAPA/AADCP, Bangkok. pp. 24-60.

Phelps, R.P. and T.J. Popma. 2000. Sex reversal of tilapia. In Tilapia aquaculture in the Americas (Eds. B.A. Costa-Pierce and J.E. Rakocy). The world aquaculture society, Baton Rouge, Louisiana, United States. pp 2:34-59.

Phelps, R.P., L.L. Lovshin and B.W. Green. 1996. Sex reversal of tilapia: $17 \alpha$-methyltestosterone dose rate by environment and efficacy of bull testes. In Pond dynamic and aquaculture collaborative research support program (Eds. D. Burle, B. Goetec, D. Clair and H. Egna). Fourteenth annual technical report. 1 Sept, 1995 to 31 July 1996. pp 89-91.

Pullin, R.S.V. 1986. Aquaculture development in Nepal, Pointers for success. Nage, the ICLARM quartely, January. pp. 9-10.

Shell, E.W. 1968. Mono-sex culture of male Tilapia nilotica Linnnaeus in ponds stocked at three rates. Proceedings FAO world symposium on warmwater pond fish culture, May 18-25, 1966, Rome, Italy, FAO fisheries report 44:353-356.

Shelton, W.L., K.D. Hopkins and G.L. Jensen. 1978. Use of hormones to produce monosex tilapia. In Culture of exotic fisheries (Eds. R.O. Smitheraman, W.L. Shelton and J.L. Grover), symposium proceedings, fish culture section, American fisheries society, Auburn, AL. pp. 1033.

Shrestha, M.K. and R.C. Bhujel. 1999. A preliminary study on nile tilapia (O. niloticus) polyculture with common carp (Cyprinus carpio) fed with duckweed (Spirodella) in Nepal. Asian fisheries science 12:83-89.

Stadtlander, T., U, Focken, B. Levavi-Sivan, H. Dweik, M. Qutob, S. Abu-Lafi, Z. Kerem and K. Becker. 2008.Treatment with saponins from Trigonella foenum-graecum and Quillaja saponaria influences sex ratio in Nile tilapia (Oreochromis niloticus) larvae.

Swingle, H.S. 1960. Comparative evaluation of two tilapia as pond fishes in Alabama. American Fisheries Society 89:142-148. http://dx.doi.org/10.1577/1548-8659 (1960) 89 [142: CEOTTA]2.0.CO;2 